\title{
Informal Labor Supply in the United States: New Estimates from the Fragile Families Survey
}

\author{
Samara Gunter ${ }^{1}$ \\ Colby College
}

October 12, 2012

\begin{abstract}
Past studies of the informal economy in the US focused on small geographic areas and select populations. This paper uses a nationally representative panel survey of urban parents, the largest and most diverse data yet, to describe the nature of informal work in the United States. Informal work is pervasive and widespread across demographic characteristics. Approximately 51 percent of urban fathers and 28 percent of urban mothers of young children pursue informal work over a five-year period. Individuals transition in and out of short, intense bouts of informal work. Conditional on participating, men work in the informal sector an average of 22 hours in a usual week (20 for women) and an average of 18 weeks during the year (18 for women).
\end{abstract}

\section{Introduction}

Although the estimated magnitude of the informal economy in the United States was between 7 and 10 percent of official gross national product during the late 1990s and 2000s (Dell’Ano and Solomon 2008; Schneider and Enste 2000; and Schneider 2005), we know relatively little about informal labor supply. Past studies of the informal economy in the US have focused on small geographic areas and select populations. This paper uses the largest and most diverse data yet, a nationally representative panel survey of urban parents, to describe the nature

\footnotetext{
${ }^{1}$ Samara R. Gunter, Department of Economics, 5230 Mayflower Hill Dr, Waterville, ME 04901, srgunter@colby.edu.
} 
of informal work in cities in the United States. It finds that informal work is pervasive and widespread across demographic characteristics.

Descriptive information about informal work in the United States can improve the design of tax systems and social services by helping policymakers understand how government policies affect family wellbeing. The extent to which individuals substitute informal work for regular work, and the sensitivity of their informal work to changes in taxes and other government policies, influences policy effectiveness. It is often impossible for program designers and evaluators to address this directly because we generally do not have good data on both policies and informal work. But learning more about the nature of informal labor supply can help policymakers think about whether their programs are likely to alter informal work patterns and estimate the importance of those effects.

Existing studies of informal work in the US and Canada have focused on particular geographic regions and select populations. ${ }^{2}$ A common weakness of these studies is that by looking only at a particular group, the studies presuppose which groups are most likely to have high informal labor force participation (Joassert 2010). We need nationally representative data to truly understand the nature of the informal workforce in the United States.

This paper updates and significantly broadens our knowledge about informal economy participation among urban households in the United States. It uses data from the The Fragile Families and Child Wellbeing Study, which was conducted in 20 US cities between 1997-2005, to describe participation in off-the-books work, work in individuals' own business, illegal activities, and other activities done for money. It describes transitions in and out of informal

\footnotetext{
${ }^{2}$ Edin and Lein (1997a, 1997b) focus on welfare and working poor mothers in four US cities. Marcelli, Pastor, and Joassert (1999) and Marcelli (2004, 2010) examine Mexicans in California. Jensen, Cornwell, and Findeis (1995) and Slack and Jensen (2010) examine rural Pennsylvania, and Larrivee and Shaffer (2007) study rural Wisconsin. Lemieux, Frechette, and Fortin (1994) and Fortin et al (1996) look at a more diverse workforce in Quebec City.
} 
work over time and characterizes the relationship between regular-sector employment and informal work.

The paper expands significantly on past studies not only due to its greater geographic scope but also because most prior studies are cross-sectional and are based on interviews or surveys conducted in the 1990s or earlier.

The longitudinal nature of the Fragile Families data reveals the prevalence of informal work. Annual rates of participation in informal work are high: between 19 and 32 percent of fathers and 12 to 16 percent of mothers report some form of informal work in each year, and over the course of five years, 51 percent of urban fathers and 28 percent of urban mothers report working informally. These estimates are much higher than revealed by previous cross-sectional studies.

Informal economy participation spells appear short but intense. Conditional on working in the informal sector, individuals work informally between 15 and 22 weeks annually on average. Averages for usual informal hours worked per week are near 20 hours per week in most waves. Consistent with the short spells, urban parents transitions into and out of the informal sector frequently. Participation in informal work is widespread across many demographic categories and crosses racial and education lines. OLS regressions relating demographic characteristics to informal work reveal few patterns. The one demographic characteristic that is strongly related to informal work is regular-sector occupation.

\section{Data}

The Fragile Families survey is unique in that it is a large-scale, longitudinal study that asks detailed questions about informal economy participation. This survey, which was designed 
to study family situations following welfare reform, also includes information on regular work as well as work off the books, in respondents' own businesses, in illegal activities (“drugs, prostitution, and other hustles”), and in other activities at four time periods.

The Fragile Families data is constructed as follows: a total of 4898 hospital births occurring between 1998 and 2000 in twenty U.S. cities with populations of over 200,000 were sampled and separate mother and father interviews were obtained at birth and at the child's first, third, and fifth birthdays. Baseline interviews took place in different years in different cities and and the resulting employment data spans years 1997 to 2005. Non-marital births were oversampled relative to marital births: approximately 75 percent of births in the sample were non-marital. Reichman et al. (2001) provide detailed information about the sampling scheme. When sample weights are used, the sample is representative of births in large US cities. ${ }^{3}$

The sample differs from the U.S. population at large in important ways. Because the sample is based on births, all survey respondents are parents. Consequently, the results of this study cannot be interpreted as indicative of the average response for the U.S. population as a whole. This is particularly true with regard to women, as mothers' work patterns in the five years following the birth of the child will differ greatly from their work experience during other life phases.

Despite these limitations, the unusually detailed panel data on informal economy participation provides an excellent opportunity to examine urban workers' participation in the informal economy. Although parents' connections to the informal economy may be different

\footnotetext{
${ }^{3}$ The Fragile Families project conducted surveys in 16 randomly sampled cities drawn from the 77 US cities with population > 200,000 in 1994. Four other cities of particular interest to the research team were also included in the survey. Applying the national weights makes the data from the 16 randomly selected cities representative of births occurring in large U.S. cities between 1998 and 2000.
} 
than those of individuals without children, this group's informal work is of particular interest because welfare and employment support policies often target these groups.

The Fragile Families survey questions about informal work attempt to capture both illegal activity and legal activities that are not reported to tax or regulatory authorities. Respondents were asked whether they participated in off-the-books work; worked in their own business; engaged in drug sales, prostitution, or other illegal activity; or did other work for cash. ${ }^{4}$ Survey professionals distinguished between informal and regular work in self-employment: they instructed respondents to include regular income from self-employment or their own business as regular-sector work. Respondents reported their earnings, weeks worked per year, and average hours worked per week for both regular and informal work. Fathers were asked these questions in all four waves, so fathers' responses cover a five-year period. Mothers answered these questions for the three waves after the baseline resulting in coverage of a four-year period.

Using survey data on informal work is challenging because respondents may not be truthful when asked about participation in illegal or informal work. Edin and Lein (1997a) warn that it is almost impossible to get accurate responses to survey questions about informal work because of the incentives to secrete income information from welfare caseworkers and other officials. This may be less true of higher-income respondents, but there is no way to know the extent of underreporting in the Fragile Families data. The likelihood of underreporting makes the high rates of informal work participation found in the data particularly noteworthy.

\section{Results}

\footnotetext{
${ }^{4}$ The survey question reads, "We are interested in finding out about some ways, other than regular work, in which people make money. This kind of activity may be paid for in cash, or done in exchange for meals, or clothing, or a place to live, or something else. Please tell me if you have done any of the following in the last twelve months: work off the books or under the table?; work in your own business?; sell or deliver drugs, engage in prostitution, or do other kinds of hustles?; do anything else to earn money?”
} 
Table 1 shows unweighted and weighted summary statistics for the full Fragile Families sample. The average age of respondents was 25 in the raw data and 27 after weighting. Three quarters of the respondents were either black or Hispanic, reflecting the oversample of nonmarital births. The unweighted sample is disproportionately low-education, with 33.5 percent of fathers and 34.7 percent of mothers reporting less than a high-school education in the first wave. Both fathers and mothers significantly increased their educational attainment over the sample period with the percentages of fathers and mothers reporting less than a high-school education falling to 28.5 percent and 26.2 percent by the fourth wave, although this may partially reflect attrition bias.

Although the survey design specified that only one quarter of the births in the sample were to married couples, an additional 43.8 percent of fathers and 36.4 percent of mothers surveyed report cohabiting. Mothers and fathers averaged 2 biological children in the first wave. Fathers' unweighted average household income was near the 1999 US median for all households of \$51,000 (2011 \$) (US Census Bureau 2011). Mothers’ average household income was lower, but well above the 1999 median of \$24,900 (2011 \$) for female householders with no spouse present. Nineteen percent of mothers reported receiving TANF benefits during the past year. Fathers were most likely to work in occupations relating to precision production, craft, or repair (25 percent at baseline); service (18 percent); or as handlers, equipment cleaners, or laborers (13.5 percent). Mothers were most likely to work in service (33 percent at baseline) or administrative support (24 percent). The differences in occupation in their regular job are likely to translate into different opportunities to work off the books.

By the fourth wave, one quarter of fathers in the sample had spent time in jail, in line with high incarceration rates for black and Hispanic men. In 2006, 1 in 15 black men and 1 in 36 
Hispanic men over 18 were incarcerated (Pew Center on the States 2008). Nearly one fifth of mothers in the sample received TANF. Almost one third of mothers and fathers had a legal child support agreement.

The unweighted data provides background information about the sample on which the estimates below are based. However, the remaining tables present weighted estimates of participation in the informal economy to illustrate the estimated overall impact of this sector on the economy. Cross-sectional weights for the mother and father samples make the data representative of parents of births between 1998-2000 in US cities with populations above 200,000 .

\section{$\underline{\text { Informal Work Patterns }}$}

Table 2 shows that most urban fathers work a regular job. Regular-sector participation ranges between 86 and 88 percent in all waves and 96 percent of urban fathers worked in the regular sector at some point during the survey period. Regular-sector labor force participation is lower for mothers and ranges from 51 percent in wave 2 to 58 percent in wave 4, and only 69 percent of urban mothers worked in the regular sector during the survey period. It is important to remember, however, that because all mothers had given birth at the time of the first wave, mothers in the sample have at least one child under age 5 living with them throughout the sample. Mothers' labor force participation does appear to increase as their children age.

Table 2 also reveals informal-sector participation rates are high. Between 19 and 32 percent of fathers and 12 to 16 percent of mothers engage in some type of informal work in each wave. These participation rates are similar to those estimated by O’Neill (1993) and somewhat higher than those found by Lemieux, Fortin, and Frechette (1994). Edin and Lein (1997a) found 
much higher annual participation rates of 32-52 percent among the subpopulation of welfare mothers and 20-37 percent of low-income wage-reliant mothers in particular cities, but their study concentrates on low-income mothers rather than all urban mothers.

Informal participation rates are lowest in wave 4 . This may be because the survey did not ask explicitly about off-the-books work in this wave even though it is the most-reported category of informal work for men in other waves. The last column of Table 2 shows cumulative participation. An impressive 51 percent of urban fathers and 28 percent of urban mothers of young children work informally during the five-year survey.

Most men who work informally also work in the regular sector. Only 12-24 percent of men each wave who participate in informal activities work exclusively in that sector. Overall, fathers reported working in both sectors in 21.6 percent of father-year observations.

Participation rates for only the informal sector range from 2.3-5.5 percent across waves. It appears that, for urban fathers of young children, informal work is almost always undertaken in conjunction with regular work. This is likely to explain why Rich, Garfinkel, and Gao (2007) do not find evidence that strong child support enforcement increases annual hours of work in the underground. Although fathers could evade child support obligations by working solely off the books, this is not consistent with these fathers' work habits.

The patterns for mothers of young children are quite different. Mothers' informal-sector participation ranges from 12-16 percent, and mothers are equally likely to work in both sectors or in only the informal sector. TANF-eligible mothers may use the informal sector to shield income from welfare agencies consistent with the findings of Edin and Lein (1997a, 1997b). Women might also be less likely to work in jobs or occupations that allow substitution between informal and regular work or women could be unable to work as many hours as men due to childcare or 
home production demands. This is consistent with the findings of Windebank and Williams (2010), who use data from the English Localities Survey and report that men’s informal work is generally more similar to regular work, while women's is more like unpaid work and is often a formal way to trade favors among friends, neighbors, and family members.

Off-the-books activities are the most common type of work for urban fathers in each wave, with 29 percent working under the table at some point during the survey and 13-16 percent working under the table in each survey wave. Almost a quarter operate their own business during the survey period. Self-reported illegal activities are much less frequent, with only 3.4 percent of men engaging in them. A fifth of men do other informal activities to earn money over the survey period, with between 6 and 10 percent engaging in other informal activities in any wave.

Urban mothers are even less likely to report illegal activities, with less than 1 percent working in self-reported hustles over the survey period. Overall, women's informal activities are almost evenly divided between work off the books, in their own businesses, and other informal activities, but in any given wave women are most likely to work off the books or in their own business. This indicates that a smaller group of women experiment with their own business, while a broader group engage in other informal activities.

Differences in type of informal work should be interpreted with caution because individuals may change how they define their work from one wave to another. For example, if a respondent paints houses for a fee, he may report this as off-the-books work in one wave but as work in his own business in the next wave. Over 40 percent of men who report informal work in two adjacent waves report different types of informal work in different waves. The summary measure of informal work is advantageous because it is not sensitive to these changes in selfreporting. 
Table 3 shows that, conditional on working in the regular sector, men work 46-48 hours per week on average while women work between 36 and 38 hours. Men usually work between 18-33 hours per week in the informal sector on average conditional on participating in informal work. Women work informally between 11 and 21 hours per week on average. The higher value reported in wave 2 appear to be caused by high reported levels of work in respondents’ own businesses. This may indicate that survey professionals were not as careful to distinguish between informal and regular work in respondents' own businesses in wave 2, and suggests that the values for the other waves are more reliable.

Respondents report working at least 10 hours per week on average for each type of informal work, conditional on participating in that form of work. Not surprisingly, work in one's own business is the most time-intensive form of informal work. Weeks and hours worked off the books are similar to those those for other informal ways to earn money. For many types of work, respondents report working between 15-20 hours per week. Informal work represents a serious time commitment on the part of many urban families. These stints of informal work appear comparatively short-lived, however. While fathers report working in the regular sector for between 47 to 49 weeks annually on average, they report working off the books for only 11-13 weeks annually and in their own business between 25-33 weeks annually. Mothers' stints in the informal sector are comparable and also shorter than their spells in the regular sector.

Table 3 also reports average reported earnings for regular work and each type of informal work, conditional on participation. The summary statistics suggest that average hourly wages in most of the informal sector are lower than in the regular sector with the exception of working in one’s own business. However, the tax advantages of working off the books would decrease or reverse the gap between the two sectors. Average informal hourly wages are almost always well 
above the minimum wage with the exception of other informal ways to earn money. These wages are similar to those found among informal day laborers in New York by Melendez and Valenzuela (2010), who point out that the hourly rate is high but that the unstable nature of day laboring results in low monthly wages.

Tables 2 and 3 show that participation rates in informal work are high, especially among men, but informal work spells are short relative to spells in the regular sector. This is consistent with the high cumulative participation rate in the informal economy over the five-year survey period, in which half of all fathers and over one fourth of mothers worked informally. The short spells and high cumulative participation suggest frequent transitions in and out of the informal sector, which are explored in Table 4.

If we consider four categories of labor force participation (regular sector only, both regular and informal sectors, informal sector only, and neither) 62 percent of men's wave-towave transitions involve no change in category, as shown in Table 4 (sum of diagonal entries). The most frequent change in categories for men is between working in the regular sector only in one wave and in both sectors in the other wave, accounting for 23 percent of wave-to-wave observations. An additional 6 percent of transitions are between the informal sector and either the regular sector, neither, or both. ${ }^{5}$

Women are similarly likely to switch from one category of labor market participation to another (58 percent of wave-to-wave observations involve no transitions) and a much higher percentage never work in either sector. For women who do change categories, the most frequent change is between regular work and no work, accounting for 20 percent of observations. Only 19

\footnotetext{
${ }^{5}$ These results are based on all adjacent wave-to-wave transitions for waves 1-4. Results are similar if only the transitions between two adjacent waves are included.
} 
percent of women's transitions involve changes in informal sector participation compared to 28 percent of men's transitions.

\section{Who Works Informally?}

The frequent transitions in and out of informal work make it challenging to identify characteristics related to these activities. If we examine only a single cross-section, we fail to capture the true population of underground workers. Consequently, we learn more about the characteristics of informal workers by regressing a dummy for ever participating in informal work during the survey period on a vector of demographic and occupational characteristics. These results cannot be interpreted as causal, but they allow us to understand which groups participate most actively in informal work and to anticipate which government policies might interact most with informal work.

Table 5 shows the results of simple pooled, unweighted OLS regressions of father and mother characteristics in the final wave on participation in different types of informal work. ${ }^{6}$ Mean marginal effects from probit regressions (available upon request) are very similar.

Fathers’ demographic and socioeconomic variables are only weakly related to informal work participation. Only citizenship status, educational attainment, and incarceration history are consistently associated with informal work. Regular-sector occupational choice is more strongly related to informal work participation than demographic characteristics. Regressions that exclude occupational information have quite low R-squared values: only 0.04 for informal work overall and 0.02 for work in own business and work in other informal activities.

Citizens are significantly more likely to report informal work than noncitizens. Since it is unlikely that non-citizens are less likely to work informally, this implies that non-citizens were

\footnotetext{
${ }^{6}$ The number of respondents who report participating in hustles is too small to permit meaningful estimation.
} 
more likely to lie to survey professionals and true rates of informal work are even higher than reported. Fathers with some post-high school education were more likely to work informally than those with a only high school diploma or GED, while those with a four-year degree were less likely to work off the books but more likely to engage in other informal ways to earn money. Spending time in jail was strongly related to informal work, indicating either that jail time creates barriers to regular-sector employment or that men who work informally are also more likely to be arrested.

Fathers' regular-sector occupation is strongly related to informal work. Interestingly, fathers who ever worked in professional or technical occupations are 10 percent more likely to have worked informally. Experience in executive, administrative and managerial jobs is also positively related to informal work. These occupational relationships indicate that high rates of informal work occur among white-collar as well as blue-collar workers, consistent with Marcelli's (2010) finding that at least 10 percent of informal workers have a college education. Still, work in precision production, craft, and repair is most strongly related with informal work, as these workers are 18 percent more likely to have worked informally. Sales workers and handlers, equipment cleaners, and laborers are also more likely to work informally, while military personnel are less likely to work off the books.

In contrast, there are almost no statistically significant relationships between mothers’ occupations and informal work participation, with the exception of precision production, craft and repair workers being 9 percent more likely to work informally overall and machine operators being 5 percent more likely to engage in other informal activities.

Demographic characteristics are much more strongly related to informal work participation for women than occupational status. Older women are less likely to report informal 
work, and both blacks and Hispanics are less likely to report informal work than whites. As with men, those with some education beyond high school are more likely to work informally. Married women are more likely to work informally and in their own business. TANF recipients are more likely to report working off the books, but not more likely to report informal work overall. Although demographic characteristics are strongly associated with informal work, they explain little of the variation in participation. The R-squared values for the mothers' regressions are quite low, never exceeding 0.33 .

Table 5 shows the results of unweighted regressions. When weights are used, there are almost no statistically significant relationships between demographic or occupational characteristics and informal work.

\section{Discussion}

The Fragile Families data indicates that urban parents of children born between 19982000 earned \$2.2 billion (2011 \$) annually in informally work during the survey period. Making the simple assumption that other adults are equally likely to work informally yields a back-ofthe-envelope calculation that indicates that total informal earnings in the US among working-age adults were approximately $\$ 50$ billion annually between 1997-2005. This is less than half a percent of GDP, far below the estimated 7-10 percent of GDP that indirect techniques suggest as the size of the informal economy (Dell'Ano and Solomon 2008; Schneider and Enste 2000; and Schneider 2005). This difference could be due to underreporting of licit informal work, due to failure of the survey to capture illegal activities, or due to measurement error in both methods.

Yet the magnitude of unreported earnings in the Fragile Families data is still large enough to have serious policy implications. The foregone payroll taxes on these earnings were \$7.6 
billion each year, about $1 \%$ of payroll tax receipts. Total informal earnings exceeded annual federal spending on each of the Earned Income Tax Credit, Temporary Assistance for Needy Families, and the Supplemental Nutrition Assistance Program during the survey period. ${ }^{7}$

Focusing on programs for low-income individuals is misleading, however, because informal work does not appear concentrated among the poor. The results above indicate that informal work is common and widespread across all socioeconomic groups. In many ways, of course, the Fragile Families is homogenous because it is composed entirely of urban workers who have recently had a child. These demographic similarities may dominate other differences in terms of informal work tendencies. Still, the finding that informal work is widespread is consistent with past research, summarized by Williams (2010), although the assumption that marginal groups are most likely to work informally persists.

What does this mean for policy? A key result for policymakers is the finding that informal work activities are generally temporary: only 3 percent of fathers and 2 percent of mothers work informally in all waves. Turnover among informal workers suggests that participation in informal work could be susceptible to policy influences and highly responsive to changes in programs. Whether this is true depends on why these spells occur and whether the decision margin is whether to work informally or formally or to work those additional hours at all.

If policymakers wish to encourage workers to report their informal activities and pay tax on them, they must simplify reporting with the temporary nature of these jobs in mind. Costly paperwork and filing procedures, whether expensive in terms of money or time, will not be worthwhile for many short-term workers.

\footnotetext{
${ }^{7}$ Combined spending on the three programs exceeded the $\$ 50$ billion in annual informal earnings.
} 
The extent to which temporary informal work can support family wellbeing may be limited by the shortness of the spells. If informal work spells end because workers have earned enough to cushion themselves, then informal work can effectively supplement family welfare. On the other hand, wellbeing may decline if the spells end because of failed businesses or exhaustion on the part of workers committing to both formal and informal work.

\section{Conclusions}

Data from the largest, most widely representative survey of informal work in the US reaffirms several results from prior studies focusing on subpopulations. Informal work is widespread across socioeconomic groups and is not limited to marginalized populations. It is common among both white-collar and blue-collar workers. Men's and women's informal work patterns differ greatly, and while men generally work in the regular and informal sectors simultaneously, women are equally likely to work in both sectors or only the informal sector.

The longitudinal aspect of the data reveals new information. The population of informal workers is even broader than previously documented, with half of all urban fathers of young children and more than a quarter of urban mothers working informally at some point during a five-year period. Workers transition in and out of short but intense informal work spells, with individuals working informally for 15-20 weeks out of a year and for about 20 hours per week, and workers transfer in and out of the informal sector over time.

Although the Fragile Families survey contributes the most comprehensive information to date on informal work in the US, many questions remain. The survey tells us nothing about the businesses that hire workers off the books, and little about work in own businesses or other activities to earn money. Past projects that examine this have focused on groups such as day 
laborers in New York (Melendez, Theodore, and Valenzuela 2010), Mexican immigrants in California (Marcelli, Pastor, and Joassert 1999; Marcelli 2004, 2010), and welfare mothers (Edin and Lein 1997a, 1999b), but we know very little about the nature of these activities among the broader population of informal workers. Further lines for inquiry include why informal work spells are both short and intense and what drives the transitions in and out of informal work.

\section{References}

Dell'Ano, Roberto and Oong Helen Solomon. 2008. "Shadow Economy and Unemployment Rate in USA: Is There a Structural Relationship? An Empirical Analysis." Applied Economics 40: 2537-2555.

Edin, Kathryn and Laura Lein. 1997a. Making Ends Meet: How Single Mothers Survive Welfare and Low-Wage Work. New York, NY: Russell Sage Foundation.

Edin, Kathryn and Laura Lein. 1997b. "Work, Welfare, and Single Mothers’ Economic Survival Strategies.” American Sociological Review 62(2): 253-266.

Fortin, Bernard, Gaetan Garneau, Guy Lacroix, Thomas Lemieux, and Claude Montmarquette. 1996. L'Economie Souterraine au Québec: Mythes et Réalités. Ste-Foy: Les Presses de l’Université Laval.

Jensen, Leif, Gretchen T. Cornwell, and Jill L. Findeis. 1995. "Informal Work in Nonmetropolitan Pennsylvania.” Rural Sociology 60(1): 91-107.

Larrivee, John and Ron E. Shaffer. 2007. "Understanding the Local Unrecorded Economy: Informal Work and Home Production in Non-Metropolitan Wisconsin.” Journal of Regional Analysis and Policy 37(2): 123-139.

Lemieux, Thomas, Bernard Fortin, and Pierre Frechette. 1994. "The Effect of Taxes on Labor Supply in the Underground Economy.” American Economic Review 84(1): 231-54.

Joassart, Pasquale. 2010. “Chapter 3: Measuring Informal Work in Developed Nations.” In Informal Work in Developed Nations. Enrico Marcelli, Colin C. Williams, and Pascale Joassert, eds. New York, NY: Routledge Advances in Heterodox Economics. 
Marcelli, Enrico A. 2004. "Unauthorized Mexican Immigration, Day Labour and other Lowerwage Informal Employment in California.” Regional Studies 38(1): 1-13.

. 2010. "Chapter 11: The Diverse Nature of Informal Work in California.” In Informal Work in Developed Nations. Enrico Marcelli, Colin C. Williams, and Pascale Joassert, eds. New York, NY: Routledge Advances in Heterodox Economics.

Marcelli, Enrico A., Manuel Pastor, Jr., and Pascale M. Joassert. 1999. "Estimating the Effects of Informal Economic Activity: Evidence from Los Angeles County.” Journal of Economic Issues 33(3): 579-607.

Melendez, Edwin, Nik Theodore, and Abel Valenzuela, Jr. 2010. "Chapter 9: Day Laborers in New York’s Informal Economy.” In Informal Work in Developed Nations. Enrico Marcelli, Colin C. Williams, and Pascale Joassert, eds. New York, NY: Routledge Advances in Heterodox Economics.

O'Neill, David M. 1983. Growth of the Underground Economy, 1950-81: Some Evidence from the Current Population Survey. Washington, D.C.: Government Printing Office.

Pew Center on the States. 2008. "One in 100: Behind Bars in America 2008.” February. Washington: The Pew Charitable Trusts. Available at http://www.pewstates.org/uploadedFiles/PCS_Assets/2008/one percent20in percent20100.pdf.

Reichman, Nancy E., Julien O. Teitler, Irwin Garfinkel, and Sara S. McLanahan. "Fragile Families: Sample and Design.” 2001. Children and Youth Services Review 23(4-5): 303-326.

Rich, Lauren M., Irwin F. Garfinkel, and Qin Gao. 2007. "Child Support Enforcement Policy and Unmarried Fathers' Employment in the Underground and Regular Economies." Journal of Policy Analysis and Management 26(4): 791-810.

Schneider, Friedrich. 2005. "The Size of Shadow Economies in 145 Countries from 1999 to 2003.” Brown Journal of World Affairs 11(2): 113-129.

Schneider, Friedrich, and Dominik H. Enste. 2000. "Shadow Economies: Size, Causes, and Consequences.” Journal of Economic Literature 38(1): 77-114.

Slack, Tim and Leif Jensen. 2010. "Chapter 12: Informal Work in Rural America: Theory and Evidence.” In Informal Work in Developed Nations. Enrico Marcelli, Colin C. Williams, and Pascale Joassert, eds. New York, NY: Routledge Advances in Heterodox Economics. 
US Census Bureau. 2011. Statistical Abstract of the United States: 2012 (131st edition). Table 699. Median Income of Families by Type of Family in Current and Constant (2009) Dollars. Washington, DC. Available at http://www.census.gov/compendia/statab/.

Williams, Colin C. 2010. "Chapter 2: The Changing Conceptualizations of Informal Work in Developed Economies.” In Informal Work in Developed Nations. Enrico Marcelli, Colin C. Williams, and Pascale Joassert, eds. New York, NY: Routledge Advances in Heterodox Economics.

Windebank, Jan and Colin C. Williams. 2010. “Chapter 6: Gender and Informal Work.” In Informal Work in Developed Nations. Enrico Marcelli, Colin C. Williams, and Pascale Joassert, eds. New York, NY: Routledge Advances in Heterodox Economics. 
Table 1

Summary Statistics

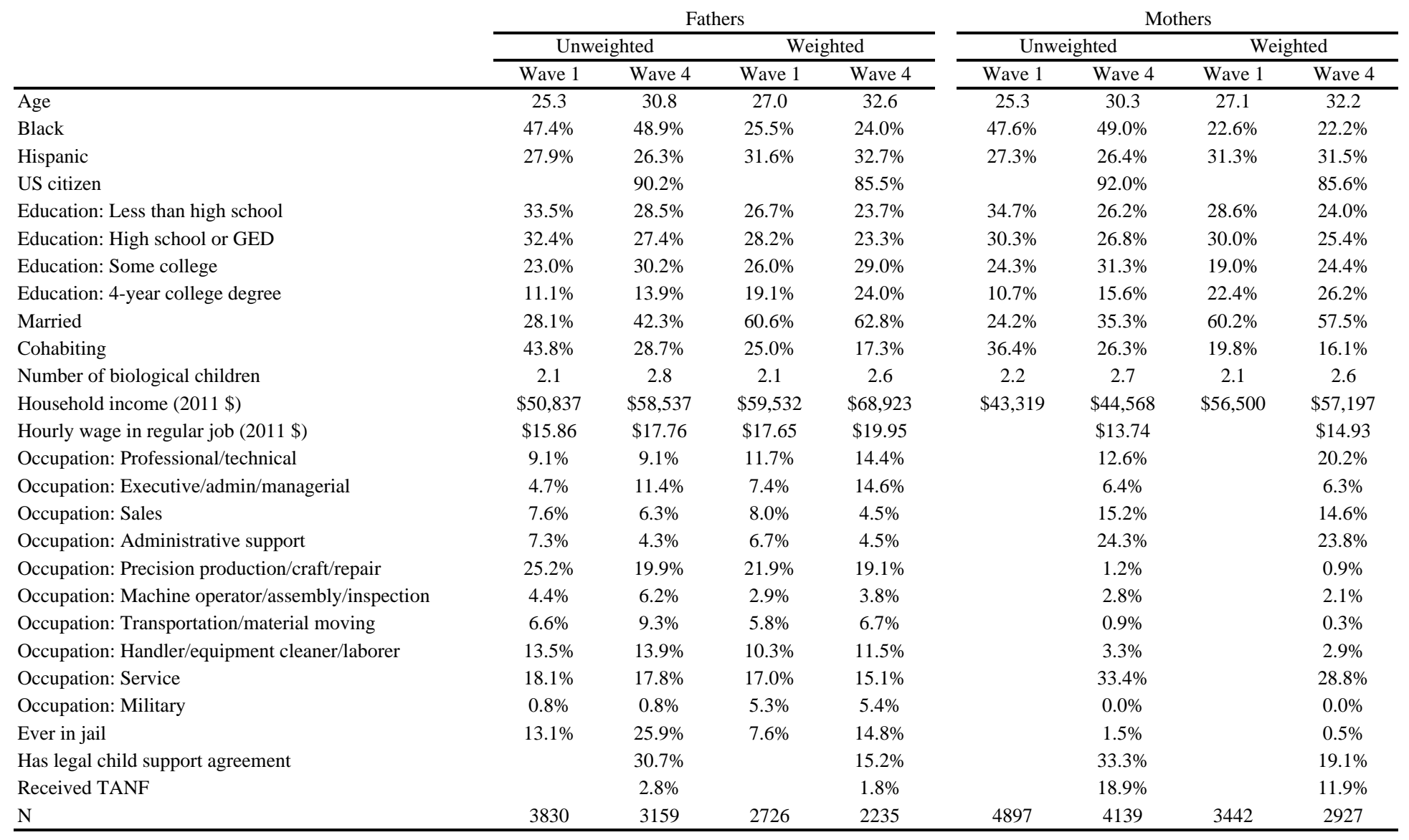

Authors' calculations using the full Fragile Families sample. Weighted estimates are representative of parents of babies born in 1998-2000 in cities with populations over 200,000. 
Table 2

Participation Rates in Regular and Informal Work

All

Wave 1 Wave 2 Wave 3 Wave 4 Waves Cumulative

\begin{tabular}{|c|c|c|c|c|c|c|}
\hline \multicolumn{7}{|l|}{ Fathers } \\
\hline Any Regular & $87.0 \%$ & $86.5 \%$ & $86.2 \%$ & $87.6 \%$ & $86.8 \%$ & $95.6 \%$ \\
\hline Any Informal & $29.6 \%$ & $32.1 \%$ & $22.7 \%$ & $18.8 \%$ & $25.7 \%$ & $51.1 \%$ \\
\hline \multicolumn{7}{|l|}{ Combinations } \\
\hline Regular Only & $61.1 \%$ & $59.4 \%$ & $69.1 \%$ & $71.2 \%$ & $65.2 \%$ & \\
\hline Regular and Informal & $25.9 \%$ & $27.1 \%$ & $17.2 \%$ & $16.4 \%$ & $21.6 \%$ & \\
\hline Informal Only & $3.8 \%$ & $4.9 \%$ & $5.5 \%$ & $2.3 \%$ & $4.1 \%$ & \\
\hline Neither & $9.3 \%$ & $8.5 \%$ & $8.3 \%$ & $10.0 \%$ & $9.0 \%$ & \\
\hline \multicolumn{7}{|l|}{ Types of Informal Work } \\
\hline Off the Books & $15.7 \%$ & $15.6 \%$ & $13.2 \%$ & & $14.8 \%$ & $28.8 \%$ \\
\hline Own Business & $9.1 \%$ & $13.3 \%$ & $5.6 \%$ & $7.5 \%$ & $8.9 \%$ & $22.7 \%$ \\
\hline Drugs, Prostitution, or Other Hustles & $1.0 \%$ & $1.4 \%$ & $1.6 \%$ & $1.3 \%$ & $1.3 \%$ & $3.4 \%$ \\
\hline Anything Else to Earn Money & $6.5 \%$ & $9.2 \%$ & $6.3 \%$ & $10.6 \%$ & $8.1 \%$ & $21.2 \%$ \\
\hline \multicolumn{7}{|l|}{ Mothers } \\
\hline Any Regular & & $51.0 \%$ & $55.0 \%$ & $58.3 \%$ & $54.8 \%$ & $68.9 \%$ \\
\hline Any Informal & & $16.1 \%$ & $15.7 \%$ & $12.1 \%$ & $14.6 \%$ & $27.6 \%$ \\
\hline \multicolumn{7}{|l|}{ Combinations } \\
\hline Regular Only & & $42.8 \%$ & $47.8 \%$ & $51.4 \%$ & $47.3 \%$ & \\
\hline Regular and Informal & & $8.2 \%$ & $7.2 \%$ & $6.9 \%$ & $7.4 \%$ & \\
\hline Informal Only & & $7.8 \%$ & $8.6 \%$ & $5.2 \%$ & $7.2 \%$ & \\
\hline Neither & & $41.2 \%$ & $36.5 \%$ & $36.6 \%$ & $38.1 \%$ & \\
\hline \multicolumn{7}{|l|}{ Types of Informal Work } \\
\hline Off the Books & & $6.5 \%$ & $8.4 \%$ & & $7.5 \%$ & $11.2 \%$ \\
\hline Own Business & & $7.6 \%$ & $5.3 \%$ & $5.3 \%$ & $6.1 \%$ & $12.3 \%$ \\
\hline Drugs, Prostitution, of Other Hustles & & $0.1 \%$ & $0.5 \%$ & $0.3 \%$ & $0.3 \%$ & $0.7 \%$ \\
\hline Anything Else to Earn Money & & $3.9 \%$ & $3.7 \%$ & $6.7 \%$ & $4.8 \%$ & $10.9 \%$ \\
\hline
\end{tabular}


Table 3

Average Hours and Weeks Worked and Earnings in the Regular and Informal Sectors (Conditional)

\begin{tabular}{|c|c|c|c|c|c|c|c|}
\hline & \multicolumn{4}{|c|}{ Fathers } & \multicolumn{3}{|c|}{ Mothers } \\
\hline & Wave 1 & Wave 2 & Wave 3 & Wave 4 & Wave 2 & Wave 3 & Wave 4 \\
\hline Regular Sector Usual Hours per Week & 45.7 & 48.6 & 48.4 & 48.4 & 36.1 & 38.2 & 38.2 \\
\hline Informal Sector Usual Hours per Week & 17.0 & 29.2 & 19.5 & 23.0 & 21.2 & 19.4 & 11.4 \\
\hline Off the Books Usual Hours per Week & 15.9 & 24.6 & 18.7 & & 16.1 & 18.4 & \\
\hline Own Business Usual Hours per Week & 22.2 & 30.0 & 17.1 & 17.9 & 25.7 & 23.8 & 9.9 \\
\hline Any Other Way to Earn Money Usual Hours Per Week & 13.7 & 27.2 & 13.4 & 26.0 & 12.4 & 13.2 & 12.1 \\
\hline Regular Sector Weeks Worked Last Year & 47.2 & 48.9 & 49.2 & 48.0 & 37.7 & 43.1 & 46.4 \\
\hline Informal Sector Weeks Worked Last Year & 15.4 & 22.3 & 16.3 & 20.4 & 14.6 & 20.3 & 17.6 \\
\hline Off the Books Weeks Worked Last Year & 11.5 & 12.9 & 11.5 & & 9.1 & 14.0 & \\
\hline Own Business Weeks Worked Last Year & 25.3 & 33.2 & 28.8 & 25.8 & 20.7 & 31.6 & 22.3 \\
\hline Any Other Way to Earn Money Weeks Worked Last Year & 11.7 & 14.0 & 10.5 & 15.3 & 7.8 & 10.9 & 14.5 \\
\hline Regular Sector Earnings Last Year & $\$ 43,195$ & $\$ 67,285$ & $\$ 64,956$ & $\$ 63,015$ & $\$ 25,654$ & $\$ 29,052$ & $\$ 32,476$ \\
\hline Informal Sector Earnings Last Year & & $\$ 17,386$ & $\$ 7,650$ & $\$ 7,999$ & $\$ 3,985$ & $\$ 6,185$ & $\$ 2,750$ \\
\hline Off the Books Weeks Earnings Last Year & & $\$ 4,717$ & $\$ 4,190$ & & $\$ 2,181$ & $\$ 1,962$ & \\
\hline Own Business Earnings Last Year & & $\$ 31,914$ & $\$ 16,361$ & $\$ 12,416$ & $\$ 5,975$ & $\$ 13,347$ & $\$ 4,510$ \\
\hline Any Other Way to Earn Money Earnings Last Year & & $\$ 5,040$ & $\$ 2,650$ & $\$ 2,843$ & $\$ 829$ & $\$ 1,135$ & $\$ 1,575$ \\
\hline Estimated Hourly Wage, Regular Sector & $\$ 20.04$ & $\$ 28.30$ & $\$ 27.26$ & $\$ 27.09$ & $\$ 18.84$ & $\$ 17.69$ & $\$ 18.30$ \\
\hline Estimated Hourly Wage, Informal Sector & & $\$ 26.63$ & $\$ 24.09$ & $\$ 17.05$ & $\$ 12.90$ & $\$ 15.69$ & $\$ 13.67$ \\
\hline Estimated Hourly Wage, Off the Books & & $\$ 14.86$ & $\$ 19.50$ & & $\$ 14.83$ & $\$ 7.63$ & \\
\hline Estimated Hourly Wage, Own Business & & $\$ 31.99$ & $\$ 33.15$ & $\$ 26.87$ & $\$ 11.21$ & $\$ 17.73$ & $\$ 20.38$ \\
\hline Estimated Hourly Wage, Any Other Way to Earn Money & & $\$ 13.26$ & $\$ 18.80$ & $\$ 7.18$ & $\$ 8.64$ & $\$ 7.93$ & $\$ 8.99$ \\
\hline
\end{tabular}

Authors' calculations using the full Fragile Families sample and weighted to be representative of parents of babies born in 1998 -2000 in cities with populations over 200,000. 
Table 4

Transitions Between Labor Force Participation Status Across Waves

Fathers

\begin{tabular}{llcccc} 
Transition between... & & Begular & $\begin{array}{c}\text { Informal } \\
\text { sector only }\end{array}$ & $\begin{array}{c}\text { Neither } \\
\text { sector }\end{array}$ \\
\hline and... & Both sectors & $10.16 \%$ & $22.86 \%$ & $2.15 \%$ & $1.48 \%$ \\
& Regular sector only & & $48.30 \%$ & $2.34 \%$ & $7.19 \%$ \\
& Informal sector only & & & $0.90 \%$ & $1.65 \%$ \\
& Neither sector & & & $2.94 \%$ \\
\hline
\end{tabular}

Mothers

\begin{tabular}{|c|c|c|c|c|c|}
\hline Transition between... & & Both sectors & $\begin{array}{c}\text { Regular } \\
\text { sector only }\end{array}$ & $\begin{array}{c}\text { Informal } \\
\text { sector only }\end{array}$ & $\begin{array}{c}\text { Neither } \\
\text { sector }\end{array}$ \\
\hline \multirow[t]{4}{*}{ and... } & Both sectors & $1.83 \%$ & $6.93 \%$ & $2.37 \%$ & $2.47 \%$ \\
\hline & Regular sector only & & $33.31 \%$ & $3.05 \%$ & $19.69 \%$ \\
\hline & Informal sector only & & & $1.53 \%$ & $7.02 \%$ \\
\hline & Neither sector & & & & $21.78 \%$ \\
\hline
\end{tabular}

Table includes all transitions between waves 1 and 2, waves 2 and 3, and waves 3 and 4. Authors' calculations using the full Fragile Families sample and weighted to be representative of parents of babies born in 1998-2000 in cities with populations over 200,000. 
Table 5

Characteristics of Urban Parents Who Work Informally During the Fragile Families Survey

\begin{tabular}{|c|c|c|c|c|c|c|c|c|}
\hline & & & & & & & & \\
\hline & $\begin{array}{c}\text { Informal } \\
\text { Work }\end{array}$ & $\begin{array}{l}\text { Off the } \\
\text { Books }\end{array}$ & $\begin{array}{c}\text { Own } \\
\text { Business }\end{array}$ & $\begin{array}{c}\text { Other } \\
\text { Informal }\end{array}$ & $\begin{array}{c}\text { Informal } \\
\text { Work }\end{array}$ & $\begin{array}{l}\text { Off the } \\
\text { Books }\end{array}$ & $\begin{array}{c}\text { Own } \\
\text { Business }\end{array}$ & $\begin{array}{c}\text { Other } \\
\text { Informal }\end{array}$ \\
\hline Demographic Characteristics, Wave 4 & & & & & & & & \\
\hline Age/10 & $\begin{array}{l}-0.02 \\
(0.02)\end{array}$ & $\begin{array}{l}-0.04 * \\
(0.01)\end{array}$ & $\begin{array}{c}0.03 \\
(0.01)\end{array}$ & $\begin{array}{l}-0.00 \\
(0.01)\end{array}$ & $\begin{array}{l}-0.03^{*} \\
(0.01)\end{array}$ & $\begin{array}{l}-0.02 * \\
(0.01)\end{array}$ & $\begin{array}{c}0.01 \\
(0.01)\end{array}$ & $\begin{array}{c}-0.03^{* *} \\
(0.01)\end{array}$ \\
\hline Black, non-Hispanic & $\begin{array}{l}-0.01 \\
(0.02)\end{array}$ & $\begin{array}{l}-0.03 \\
(0.02)\end{array}$ & $\begin{array}{c}0.02 \\
(0.02)\end{array}$ & $\begin{array}{l}-0.01 \\
(0.02)\end{array}$ & $\begin{array}{c}-0.06^{* *} \\
(0.02)\end{array}$ & $\begin{array}{c}-0.04 * * \\
(0.01)\end{array}$ & $\begin{array}{l}0.03^{*} \\
(0.01)\end{array}$ & $\begin{array}{c}-0.05^{* *} \\
(0.02)\end{array}$ \\
\hline Hispanic & $\begin{array}{l}-0.05 \\
(0.03)\end{array}$ & $\begin{array}{l}-0.03 \\
(0.03)\end{array}$ & $\begin{array}{l}-0.04 \\
(0.02)\end{array}$ & $\begin{array}{l}-0.02 \\
(0.02)\end{array}$ & $\begin{array}{c}-0.12^{* *} \\
(0.02)\end{array}$ & $\begin{array}{c}-0.05^{* *} \\
(0.02)\end{array}$ & $\begin{array}{l}-0.03 * \\
(0.01)\end{array}$ & $\begin{array}{c}-0.09 * * \\
(0.02)\end{array}$ \\
\hline US citizen & $\begin{array}{c}0.16^{* *} \\
(0.03)\end{array}$ & $\begin{array}{c}0.14^{* *} \\
(0.03)\end{array}$ & $\begin{array}{c}0.01 \\
(0.03)\end{array}$ & $\begin{array}{l}0.10^{* *} \\
(0.02)\end{array}$ & $\begin{array}{c}0.05 \\
(0.03)\end{array}$ & $\begin{array}{c}0.02 \\
(0.02)\end{array}$ & $\begin{array}{c}0.01 \\
(0.02)\end{array}$ & $\begin{array}{l}0.05^{* *} \\
(0.02)\end{array}$ \\
\hline Less than high-school education & $\begin{array}{c}0.04 \\
(0.02)\end{array}$ & $\begin{array}{c}0.03 \\
(0.02)\end{array}$ & $\begin{array}{l}-0.00 \\
(0.02)\end{array}$ & $\begin{array}{l}-0.01 \\
(0.02)\end{array}$ & $\begin{array}{c}0.03 \\
(0.02)\end{array}$ & $\begin{array}{c}0.01 \\
(0.02)\end{array}$ & $\begin{array}{c}0.00 \\
(0.01)\end{array}$ & $\begin{array}{c}0.03 \\
(0.02)\end{array}$ \\
\hline Some post-high-school education & $\begin{array}{c}0.07 * * \\
(0.02)\end{array}$ & $\begin{array}{c}0.03 \\
(0.02)\end{array}$ & $\begin{array}{c}0.05^{* *} \\
(0.02)\end{array}$ & $\begin{array}{c}0.02 \\
(0.02)\end{array}$ & $\begin{array}{l}0.05^{*} \\
(0.02)\end{array}$ & $\begin{array}{c}0.00 \\
(0.01)\end{array}$ & $\begin{array}{l}0.03^{*} \\
(0.01)\end{array}$ & $\begin{array}{l}0.03^{*} \\
(0.01)\end{array}$ \\
\hline 4-year college degree & $\begin{array}{c}0.06 \\
(0.04)\end{array}$ & $\begin{array}{l}-0.08 * \\
(0.03)\end{array}$ & $\begin{array}{l}-0.01 \\
(0.03)\end{array}$ & $\begin{array}{l}0.08^{*} \\
(0.03)\end{array}$ & $\begin{array}{l}0.06^{*} \\
(0.03)\end{array}$ & $\begin{array}{l}-0.01 \\
(0.02)\end{array}$ & $\begin{array}{c}0.04 \\
(0.02)\end{array}$ & $\begin{array}{c}0.03 \\
(0.02)\end{array}$ \\
\hline Currently married & $\begin{array}{c}0.00 \\
(0.03)\end{array}$ & $\begin{array}{l}-0.04 \\
(0.03)\end{array}$ & $\begin{array}{c}0.01 \\
(0.02)\end{array}$ & $\begin{array}{c}0.02 \\
(0.02)\end{array}$ & $\begin{array}{l}0.05^{*} \\
(0.02)\end{array}$ & $\begin{array}{c}0.01 \\
(0.01)\end{array}$ & $\begin{array}{c}0.06^{* *} \\
(0.01)\end{array}$ & $\begin{array}{c}0.02 \\
(0.02)\end{array}$ \\
\hline Currently cohabiting with partner & $\begin{array}{c}0.03 \\
(0.02)\end{array}$ & $\begin{array}{c}0.04 \\
(0.02)\end{array}$ & $\begin{array}{l}-0.00 \\
(0.02)\end{array}$ & $\begin{array}{c}0.02 \\
(0.02)\end{array}$ & $\begin{array}{c}0.01 \\
(0.02)\end{array}$ & $\begin{array}{c}0.00 \\
(0.01)\end{array}$ & $\begin{array}{l}-0.00 \\
(0.01)\end{array}$ & $\begin{array}{c}0.01 \\
(0.01)\end{array}$ \\
\hline Number of biological children & $\begin{array}{c}0.00 \\
(0.01)\end{array}$ & $\begin{array}{l}-0.00 \\
(0.01)\end{array}$ & $\begin{array}{l}-0.00 \\
(0.01)\end{array}$ & $\begin{array}{l}-0.00 \\
(0.01)\end{array}$ & $\begin{array}{c}0.01 \\
(0.01)\end{array}$ & $\begin{array}{c}0.00 \\
(0.01)\end{array}$ & $\begin{array}{l}-0.01 \\
(0.01)\end{array}$ & $\begin{array}{c}0.00 \\
(0.01)\end{array}$ \\
\hline Number of children living in household & $\begin{array}{l}-0.01 \\
(0.01)\end{array}$ & $\begin{array}{l}-0.00 \\
(0.01)\end{array}$ & $\begin{array}{c}0.00 \\
(0.01)\end{array}$ & $\begin{array}{l}-0.00 \\
(0.01)\end{array}$ & $\begin{array}{c}-0.02 * \\
(0.01)\end{array}$ & $\begin{array}{l}-0.01 \\
(0.01)\end{array}$ & $\begin{array}{l}-0.00 \\
(0.01)\end{array}$ & $\begin{array}{l}-0.01 \\
(0.01)\end{array}$ \\
\hline Household income, thousands (2011 \$) & $\begin{array}{l}-0.00 \\
(0.00)\end{array}$ & $\begin{array}{c}0.00 \\
(0.00)\end{array}$ & $\begin{array}{c}0.00 \\
(0.00)\end{array}$ & $\begin{array}{l}-0.00 \\
(0.00)\end{array}$ & $\begin{array}{l}-0.00 * \\
(0.00)\end{array}$ & $\begin{array}{l}-0.00 * \\
(0.00)\end{array}$ & $\begin{array}{l}-0.00 \\
(0.00)\end{array}$ & $\begin{array}{l}-0.00 \\
(0.00)\end{array}$ \\
\hline Hourly wage in most recent regular job/10 (2011 \$) & $\begin{array}{l}-0.02 \\
(0.01)\end{array}$ & $\begin{array}{c}-0.03^{* *} \\
(0.01)\end{array}$ & $\begin{array}{l}-0.00 \\
(0.01)\end{array}$ & $\begin{array}{c}0.00 \\
(0.01)\end{array}$ & $\begin{array}{l}-0.02 \\
(0.01)\end{array}$ & $\begin{array}{l}-0.00 \\
(0.01)\end{array}$ & $\begin{array}{l}-0.00 \\
(0.01)\end{array}$ & $\begin{array}{c}-0.02^{* *} \\
(0.01)\end{array}$ \\
\hline Has legal child support order & $\begin{array}{c}0.01 \\
(0.02)\end{array}$ & $\begin{array}{c}0.02 \\
(0.02)\end{array}$ & $\begin{array}{l}-0.01 \\
(0.02)\end{array}$ & $\begin{array}{c}0.02 \\
(0.02)\end{array}$ & $\begin{array}{c}0.01 \\
(0.02)\end{array}$ & $\begin{array}{c}0.00 \\
(0.01)\end{array}$ & $\begin{array}{c}-0.01 \\
(0.01)\end{array}$ & $\begin{array}{c}0.02 \\
(0.01)\end{array}$ \\
\hline
\end{tabular}




\begin{tabular}{|c|c|c|c|c|c|c|c|c|}
\hline Ever spent time in jail & $\begin{array}{c}0.10^{* *} \\
(0.02)\end{array}$ & $\begin{array}{c}0.07^{* *} \\
(0.02)\end{array}$ & $\begin{array}{c}0.01 \\
(0.02)\end{array}$ & $\begin{array}{l}0.04 * \\
(0.02)\end{array}$ & & & & \\
\hline Received TANF in last year & & & & & $\begin{array}{c}0.02 \\
(0.02)\end{array}$ & $\begin{array}{l}0.04^{*} \\
(0.02)\end{array}$ & $\begin{array}{l}-0.01 \\
(0.01)\end{array}$ & $\begin{array}{c}0.03 \\
(0.02)\end{array}$ \\
\hline \multicolumn{9}{|l|}{ Occupational History } \\
\hline Ever worked in: Professional/technical & $\begin{array}{c}0.10^{* *} \\
(0.03)\end{array}$ & $\begin{array}{l}0.06^{*} \\
(0.03)\end{array}$ & $\begin{array}{c}0.12^{* *} \\
(0.03)\end{array}$ & $\begin{array}{c}0.08 * * \\
(0.03)\end{array}$ & $\begin{array}{c}0.04 \\
(0.02)\end{array}$ & $\begin{array}{c}0.01 \\
(0.02)\end{array}$ & $\begin{array}{c}0.03 \\
(0.02)\end{array}$ & $\begin{array}{l}0.03^{*} \\
(0.02)\end{array}$ \\
\hline Ever worked in: Executive/admin/managerial & $\begin{array}{l}0.07^{* *} \\
(0.02)\end{array}$ & $\begin{array}{c}0.04 \\
(0.02)\end{array}$ & $\begin{array}{l}0.09^{* *} \\
(0.02)\end{array}$ & $\begin{array}{l}0.05^{*} \\
(0.02)\end{array}$ & $\begin{array}{c}0.04 \\
(0.02)\end{array}$ & $\begin{array}{c}0.02 \\
(0.02)\end{array}$ & $\begin{array}{c}0.03 \\
(0.02)\end{array}$ & $\begin{array}{c}0.01 \\
(0.02)\end{array}$ \\
\hline Ever worked in: Sales & $\begin{array}{l}0.09 * * \\
(0.02)\end{array}$ & $\begin{array}{c}0.02 \\
(0.02)\end{array}$ & $\begin{array}{l}0.08^{* *} \\
(0.02)\end{array}$ & $\begin{array}{c}0.04 \\
(0.02)\end{array}$ & $\begin{array}{l}0.04^{*} \\
(0.02)\end{array}$ & $\begin{array}{c}0.02 \\
(0.01)\end{array}$ & $\begin{array}{c}0.02 \\
(0.01)\end{array}$ & $\begin{array}{l}0.03^{*} \\
(0.01)\end{array}$ \\
\hline Ever worked in: Administrative support & $\begin{array}{l}-0.02 \\
(0.02)\end{array}$ & $\begin{array}{l}-0.00 \\
(0.02)\end{array}$ & $\begin{array}{l}-0.02 \\
(0.02)\end{array}$ & $\begin{array}{c}0.01 \\
(0.02)\end{array}$ & $\begin{array}{c}0.02 \\
(0.02)\end{array}$ & $\begin{array}{c}0.02 \\
(0.01)\end{array}$ & $\begin{array}{c}0.02 \\
(0.01)\end{array}$ & $\begin{array}{c}0.02 \\
(0.01)\end{array}$ \\
\hline Ever worked in: Precision production/craft/repair & $\begin{array}{c}0.18^{* *} \\
(0.02)\end{array}$ & $\begin{array}{c}0.23^{* *} \\
(0.02)\end{array}$ & $\begin{array}{c}0.10^{* *} \\
(0.02)\end{array}$ & $\begin{array}{c}0.06^{* *} \\
(0.02)\end{array}$ & $\begin{array}{l}0.11^{*} \\
(0.04)\end{array}$ & $\begin{array}{c}0.04 \\
(0.03)\end{array}$ & $\begin{array}{c}0.05 \\
(0.03)\end{array}$ & $\begin{array}{c}0.02 \\
(0.03)\end{array}$ \\
\hline Ever worked in: Machine operator/assem/inspection & $\begin{array}{c}0.01 \\
(0.03)\end{array}$ & $\begin{array}{c}0.00 \\
(0.03)\end{array}$ & $\begin{array}{c}0.04 \\
(0.02)\end{array}$ & $\begin{array}{c}0.03 \\
(0.02)\end{array}$ & $\begin{array}{l}0.08^{*} \\
(0.03)\end{array}$ & $\begin{array}{c}0.01 \\
(0.02)\end{array}$ & $\begin{array}{c}0.04 \\
(0.02)\end{array}$ & $\begin{array}{l}0.06^{*} \\
(0.02)\end{array}$ \\
\hline Ever worked in: Transportation/material moving & $\begin{array}{c}0.00 \\
(0.02)\end{array}$ & $\begin{array}{l}-0.01 \\
(0.02)\end{array}$ & $\begin{array}{c}0.03 \\
(0.02)\end{array}$ & $\begin{array}{c}0.02 \\
(0.02)\end{array}$ & $\begin{array}{l}-0.00 \\
(0.06)\end{array}$ & $\begin{array}{c}0.04 \\
(0.04)\end{array}$ & $\begin{array}{l}-0.02 \\
(0.04)\end{array}$ & $\begin{array}{l}-0.06 \\
(0.04)\end{array}$ \\
\hline Ever worked in: Handler/equip cleaner/laborer & $\begin{array}{c}0.07^{* *} \\
(0.02)\end{array}$ & $\begin{array}{c}0.08^{* *} \\
(0.02)\end{array}$ & $\begin{array}{l}-0.01 \\
(0.02)\end{array}$ & $\begin{array}{c}0.05^{* *} \\
(0.02)\end{array}$ & $\begin{array}{l}0.08^{*} \\
(0.03)\end{array}$ & $\begin{array}{c}0.04 \\
(0.02)\end{array}$ & $\begin{array}{c}0.03 \\
(0.02)\end{array}$ & $\begin{array}{c}0.05 \\
(0.02)\end{array}$ \\
\hline Ever worked in: Service & $\begin{array}{c}0.04 \\
(0.02)\end{array}$ & $\begin{array}{c}0.03 \\
(0.02)\end{array}$ & $\begin{array}{c}0.01 \\
(0.02)\end{array}$ & $\begin{array}{c}0.08^{* *} \\
(0.02)\end{array}$ & $\begin{array}{c}0.11 * * \\
(0.02)\end{array}$ & $\begin{array}{l}0.08^{* *} \\
(0.01)\end{array}$ & $\begin{array}{c}0.06^{* *} \\
(0.01)\end{array}$ & $\begin{array}{l}0.03^{*} \\
(0.01)\end{array}$ \\
\hline Ever worked in: Other/Unspecified & $\begin{array}{l}0.12^{*} \\
(0.05)\end{array}$ & $\begin{array}{c}0.05 \\
(0.05)\end{array}$ & $\begin{array}{l}0.16^{* *} \\
(0.04)\end{array}$ & $\begin{array}{c}0.04 \\
(0.04)\end{array}$ & $\begin{array}{c}0.04 \\
(0.07)\end{array}$ & $\begin{array}{c}0.02 \\
(0.05)\end{array}$ & $\begin{array}{c}0.01 \\
(0.05)\end{array}$ & $\begin{array}{l}-0.01 \\
(0.05)\end{array}$ \\
\hline Ever worked in: Military & $\begin{array}{l}-0.07 \\
(0.08)\end{array}$ & $\begin{array}{l}-0.15^{*} \\
(0.06)\end{array}$ & $\begin{array}{l}-0.05 \\
(0.06)\end{array}$ & $\begin{array}{c}0.07 \\
(0.07)\end{array}$ & & & & \\
\hline Constant & $\begin{array}{l}0.34 * * \\
(0.07)\end{array}$ & $\begin{array}{c}0.27 * * \\
(0.06)\end{array}$ & $\begin{array}{c}0.00 \\
(0.06)\end{array}$ & $\begin{array}{c}0.00 \\
(0.05)\end{array}$ & $\begin{array}{c}0.31^{* *} \\
(0.06)\end{array}$ & $\begin{array}{c}0.17^{* *} \\
(0.04)\end{array}$ & $\begin{array}{c}0.01 \\
(0.04)\end{array}$ & $\begin{array}{c}0.17 * * \\
(0.04)\end{array}$ \\
\hline R-squared & 0.076 & 0.118 & 0.051 & 0.029 & 0.033 & 0.028 & 0.025 & 0.026 \\
\hline $\mathrm{N}$ & 3027 & 3027 & 3027 & 3027 & 3890 & 3890 & 3890 & 3890 \\
\hline
\end{tabular}

